\title{
Enzymatic Treatment of Soft Jackfruit (Artocarpus heterophyllus) Pulp With Two Commercial Pectinases: Physical Properties and Viscosity Analysis
}

\author{
Edinara Lacerda Queiroz (Corresponding author) \\ Dept. of Technology, State University of Feira de Santana \\ 44036900, Feira de Santana, Bahia \\ E-mail: edinaralacerdaq@gmail.com
}
Tamires Bastos de Almeida
Dept. of Technology, State University of Feira de Santana 44036900, Feira de Santana, Bahia
E-mail: tamires.b.a@outlook.com
Sílvia Maria Almeida de Souza
Dept. of Technology, State University of Feira de Santana 44036900, Feira de Santana, Bahia
E-mail: ss_almeida@uefs.br

\section{Ernesto Acosta Martinez}

Dept. of Technology, State University of Feira de Santana 44036900, Feira de Santana, Bahia E-mail: ernesto.amartinez@yahoo.com.br

Received: July 8, 2020 Accepted: December 30, $2020 \quad$ Published: January 20, 2021

Doi: 10.5296/jab.v9i1.17331 URL: https://doi.org/10.5296/jab.v9i1.17331 


\begin{abstract}
The aim of this study was to investigate the effect of enzyme hydrolysis of jackfruit pulp using two commercial pectinase enzyme solutions with different polygalacturonase activities. A $2^{3}$ factorial design, with three repetitions at the central point, was used to establish the optimal conditions of jackfruit pulp hydrolysis, evaluating the effect of time (20 - $100 \mathrm{~min})$, temperature $\left(30-60^{\circ} \mathrm{C}\right)$ and enzyme concentration $(0.01-0.09 \%)$. The dependent variables viscosity, yield, soluble solids content, color intensity, shade, and turbidity were the responses evaluated. Viscosity, color intensity, shade, and turbidity of the pulps were significantly influenced by all studied variables with the determination coefficients $\left(\mathrm{R}^{2}\right)$ between 0.74 and 0.99. The lack of adjustment was not significant in the models that describe the previous properties. The highest enzyme concentration $(0.09 \%)$ was the factor with the greatest influence on the studied responses, regardless of the pectinase type.
\end{abstract}

Keywords: Jackfruit, Pectinex Ultra SP-L, Pectinex UltraClear, Viscosity

\title{
1. Introduction
}

Brazil is the world's third largest fruit producer, behind China and India only (Andrade, 2017). Brazilian horticulture serves consumers from around 100 countries all over the world, but much of its production is for domestic consumption (Brazilian fruit yearbook, 2017). Horticulture is a huge part of the country's economy, with an important socio-economic role. The fruit sector is one of the largest incomes and rural development generators of agribusiness in the country, with significant social importance, especially in poorer regions, which have no better alternatives to boost their economy (Fachinello et al., 2011; Buainain \& Batalha, 2007). The jackfruit (Artocarpus heterophyllus Lam., Family - Moraceae) tree is a wild plant bearing the largest known edible fruit (up to $35 \mathrm{~kg}$ ) and is distributed throughout the tropics and subtropics (Jagtap et al., 2011). Due to its spontaneous proliferation in warmer regions (specifically Brazil), it is now cultivated throughout the Amazon region and tropical coast of Brazil, from the states of Pará down to Rio de Janeiro (Souza et al., 2009). Jackfruits usually weigh between $4.5-30 \mathrm{~kg}$ (commonly $9-18 \mathrm{~kg}$ ), with a maximum reported weight of $50 \mathrm{~kg}$. The exterior of the compound fruit is green, turning to yellow when ripe. The interior consists of large yellow edible bulbs which enclose a smooth, oval, light-brown seed (Goswami \& Chacrabati, 2016). The edible bulbs of ripe jackfruit are consumed fresh or processed into various products (Begum et al., 2014).

Their consistency can be slightly hard or completely soft, hence the distinction of the two varieties popularly known as "soft jackfruit" and "hard jackfruit" (Silva et al., 2007). About $60 \%$ of the whole fruit is inedible consisting of the outer prickly rind, inner perigones (non-edible perianth) and central core, which are unutilized waste (Subburamu et al., 1992).

The jackfruit has several uses. Young fruits and seeds used as vegetables, because they contain high carbohydrate and protein contents. Normally, the young fruits and seeds can be discarded or steamed and eaten as a snack as used in some local dishes (Tulyathana et al., 2002). The pulp of ripe jackfruit is eaten fresh and used in fruit salads, jam and juices, as it possesses high nutritional value (Jagtap et al., 2010). Mature jackfruits are also cooked as vegetables, and used in curries or salads (Swami et al., 2012). In addition, jackfruit is a product with great potential 
as a manufactured fermented beverage because the concentration of the carbohydrates is above $10 \%$ (Asquieri et al., 2008). Jackfruit is rich in protein, starch, minerals, and vitamins specifically calcium and thiamine. In addition, it contains great measures of vitamin B-6 (pyridoxine), niacin, riboflavin and folic acid (Udayasoorian et al., 2019). The pulp has excellent visco-elastic properties and adequate build-up of soluble solids. The versatile tree has served the needs of rural communities considerably by providing food, nutrition and many other traditional medications to the people of Southeast Asia, Indonesia, the western part of Java and India (Jagtap \& Bapat, 2010). The current research's focus is to assess the potential of underutilized tropical fruit species in order to meet the growing needs of the consumer market for several by-products, including wine (Jagtap et al., 2011).

Pectic substances are high molecular weight glycosidic macromolecules that form the largest component of the middle lamella, a thin layer of extracellular adhesive material between the primary walls of plant cells (Almeida et al., 2005). Pectins have high capacity for binding water because of the presence of hydrophilic $(-\mathrm{OH})$ groups. Pectic enzymes disrupt these bonds enabling the water, in the form of juice, to be released during fruit juice extraction (Kumar, 2015).

Enzymes have been used for food processing for as long as humankind has processed food. The use of enzymes in the food industry is based on three basic aspects: to control the quality of foods, to be used as food additives, and to modify the properties of some food additives and the food itself, modifying the physicochemical and rheological properties (Patel et al., 2016).

The use of enzymes or microorganisms in food preparations is an age-old process. With the advancement of technology, novel enzymes with wide range of applications and specificity have been developed and new application areas are still being explored (Raveendran et al., 2018). Pectinases are widely used in the fruit juice industry to reduce viscosity and improve filtration and clarification efficiency in the preliminary treatment of grapes in the wine industry (Uenojo \& Pastore, 2007).

With the addition of enzymes such as pectinases, the viscosity of the fruit juice decreases, the press ability of the pulp improves, the jelly structure disintegrates and the fruit juice is easily obtained with higher yields (Tapre \& Jain, 2014). The enzyme treatment for hydrolysis of pectic substances are influenced by several factors such as incubation time and temperature, enzyme concentration, shaking, and substrate concentration (Lee et al., 2006).

The juice extraction and clarification are the main uses for pectinases (Jayani, Saxena \& Gupta, 2005). Juice clarification is the oldest and largest market for commercial pectinases. (Baumann, 1981). Enzymatic processing makes the juice clear by breaking down the pectin and allowing the suspended particles to settle down and eliminate undesirable changes in color and stability. For tropical fruit juices it represents a real alternative method to diversify the industrial production (Tapre \& Jain, 2014).

Many researchers have used pectinolytic enzymes in their work, aiming to reduce the viscosity and clarification of fruit juices such as guava, blackcurrant, plum, carambola fruit, banana, sapodilla and mango (Ninga et al., 2018; Mieszczakowska-Frac et al., 2012; Liew Abdullah et al., 2007; Lee et al., 2006; Sin et al., 2006; Bhattacharya \& Rastogi, 1998). The treatment with pectinolytic enzymes has also been used in fermentation processes to produce wine, cider and 
bioethanol (Cheirsilp \& Umsakul, 2008; Pollard \& Kieser, 1951; Rezic et al., 2013).

The objective of this work was to evaluate the use of commercial enzyme preparations in the juice hydrolysis of one variety of jackfruit (soft). The influence of enzyme concentration, incubation time and temperature were evaluated on the parameters: viscosity, yield, turbidity, shade and color intensity of the hydrolysed pulps, using the response surface methodology.

\section{Method}

\subsection{Materials}

The jackfruit of the soft variety used in this study was obtained from the 2018 crop in farms located in the city of Amélia Rodrigues, Bahia, Brazil.

\subsubsection{Enzyme Source}

The commercial enzyme solutions Pectinex Ultra SP-L and Pectinex UltraClear were produced by Novozymes (Denmark) and supplied by LNF Latino Americana (Brazil). The enzyme Pectinex Ultra SP-L (PSPL) has polygalacturonase activity (3800 PGNU / mL) and is commercially synthesized by the Aspergillus aculeatus microorganism. Pectinex Ultra Clear (PUC), which has polygalacturonase and pectin lyase activity (7900 PGNU/mL), is synthesized by Aspergillus niger and Aspergillus aculeatus microorganisms. Both pectinases hydrolyse (1,4)-alpha-D-galactosiduronic bonds in pectate and other galacturonans.

\subsection{Methods}

\subsubsection{Pulp Production}

The achievement of jackfruit pulp was carried out at the Food Processing Laboratory of the State University of Feira de Santana. The process began with the fruits' washing in running water and subsequent sanitization in a $200 \mathrm{ppm}$ chlorinated solution, bulbs selection and pulping in an industrial blender. The pulp was stored in properly sealed polyethylene bags and frozen at $-18^{\circ} \mathrm{C}$ until the moment of its use.

\subsubsection{Enzymatic Treatment of the Pulp}

The pulp was diluted using a ratio of one-part pulp to two parts water, according the methodology proposed by Lee et al. (2006), with adaptations. Soft jackfruit has a pulp with extremely high viscosity, and the dilution is necessary to reduce the total soluble solids. The juice was homogenized and heated to the test temperature in a thermostatic bath. The enzyme treatment was carried out in $250 \mathrm{~mL}$ Erlenmeyer flasks containing $120 \mathrm{~mL}$ of solution, heated in a thermostatic bath (Nova Ética) and stirred at $150 \mathrm{rpm}$.

The tests were performed according to a $2^{3}$ factorial design with 3 repetitions at the central point. The independent variables evaluated were incubated at time $\mathrm{X}_{1}$ (20 to $100 \mathrm{~min}$ ), temperature $\mathrm{X}_{2}\left(30\right.$ to $\left.60^{\circ} \mathrm{C}\right)$ and enzyme concentration $\mathrm{X}_{3}(0.01$ to $0.09 \% \mathrm{v} / \mathrm{v})$. The experimental design matrix with coded and decoded values, 8 trials and 3 repetitions at the central point is described in Table 1. 
Table 1. Factorial design $\left(2^{3}\right)$ with real values $(X)$ and coded $(x)$ for the variables time (1), temperature (2) and enzyme concentration (3) for enzyme treatment of jackfruit pulp

\begin{tabular}{llll}
\hline Test & $\begin{array}{l}\text { time } \\
(\mathrm{min})\end{array}$ & $\begin{array}{l}\text { Temperature } \\
\left({ }^{\circ} \mathrm{C}\right)\end{array}$ & $\begin{array}{l}\text { Enzyme concentration } \\
(\%)\end{array}$ \\
\cline { 2 - 3 }$X_{1}\left(x_{1}\right)$ & $X_{2}\left(x_{2}\right)$ & $X_{3}\left(x_{3}\right)$ \\
\hline 1 & $100(1)$ & $60(1)$ & $0.09(1)$ \\
3 & $100(1)$ & $60(1)$ & $0.01(-1)$ \\
4 & $100(1)$ & $30(-1)$ & $0.09(1)$ \\
5 & $100(1)$ & $30(-1)$ & $0.01(-1)$ \\
6 & $20(-1)$ & $60(1)$ & $0.09(1)$ \\
7 & $20(-1)$ & $60(1)$ & $0.01(-1)$ \\
8 & $20(-1)$ & $30(-1)$ & $0.09(1)$ \\
9 & $20(-1)$ & $30(-1)$ & $0.01(-1)$ \\
10 & $60(0)$ & $45(0)$ & $0.05(0)$ \\
11 & $60(0)$ & $45(0)$ & $0.05(0)$ \\
\hline 6 & $60(0)$ & $45(0)$ & $0.05(0)$
\end{tabular}

Values in parentheses denote coded level of variables.

At the end of the treatment, the enzyme was inactivated by heating the solution in a water bath to $85^{\circ} \mathrm{C} / 5 \mathrm{~min}$ and cooled to $30^{\circ} \mathrm{C}$. The samples were then centrifuged $(2000 \mathrm{xg})$ for $10 \mathrm{~min}$ (Excelsa Baby I Centrifuge - Fanem, Brazil).

The linear models for each studied variable as well as their interactions are represented using a first order polynomial function, shown below:

$$
y=b_{0}+b_{1} X_{1}+b_{2} X_{2}+b_{3} X_{3}+b_{12} X_{1} X_{2}+b_{13} X_{1} X_{3}+b_{23} X_{2} X_{3}
$$

The coefficients of the equation are represented by $b_{0}$ (constant), $b_{1}, b_{2}$ and $b_{3}$ (linear terms) and $b_{12}, b_{13}$ and $b_{23}$ (effects of interactions between variables).

\subsubsection{Viscosity Analysis}

The viscosity of the samples was determined using a Brookfield viscometer, model DV II + Pro and Spindle S-04, with a speed of $30 \mathrm{rpm}$ and a temperature of $24^{\circ} \mathrm{C}$.

\subsubsection{Juice Yield}

The hydrolysis yield was determined after centrifugation by the ratio of the amount of supernatant (clarified fraction) to the amount of decanted solids. 


\subsubsection{Turbidity}

The turbidity of the hydrolysed pulp was determined by measuring the transmittance at $660 \mathrm{~nm}$, using a Model 600 Plus UV/Vis Femto spectrophotometer, according to the methodology proposed by Reed, Hendrix \& Hendrix (1986), using distilled water as a reference.

\subsubsection{Color Analysis}

Color measurements were determined by measuring the absorbance at 420, 520 and $620 \mathrm{~nm}$ using a Model 600 Plus UV/Vis Femto spectrophotometer, according to the methodology proposed by Glories (1984). The shade was determined from the absorbance reading at wavelengths of 420 and $520 \mathrm{~nm}$ in a UV/Vis spectrophotometer, and color is determined form the absorbance reading at wavelengths of 420,520 and $620 \mathrm{~nm}$.

Color intensity (I) is considered to be the sum of each absorbance:

$$
\mathrm{I}=\mathrm{A} 420+\mathrm{A} 520+\mathrm{A} 620
$$

Shade (S) is the quotient between the absorbances at 420 and $520 \mathrm{~nm}$ :

$$
\mathrm{S}=\mathrm{A} 420 / \mathrm{A} 520
$$

\subsubsection{Experimental Design and Statistical Analysis}

A statistical analysis was performed using the software Statistica 7.0, generating the experimental design, data analysis and regression model. The results were analysed using response surface and the analysis of variance (ANOVA) methodology.

\section{Results and Discussion}

\subsection{Physicochemical characteristics and viscosity of the hydrolysed pulps: Statistical Analysis}

The values of viscosity, soluble solids content, color intensity, shade, turbidity, and yield of soft jackfruit pulp clarification after enzyme treatment with Pectinex Ultra SP-L and Pectinex Ultra Clear are shown in Table 2.

Table 2. Physicochemical properties of jackfruit pulps obtained after enzyme hydrolysis with

\begin{tabular}{|c|c|c|c|c|c|c|c|c|c|c|c|c|}
\hline \multirow[t]{2}{*}{ Test } & \multicolumn{4}{|c|}{ Viscosity (cP) Yield (\%) } & $\begin{array}{l}\text { Solubl } \\
\left({ }^{\circ} \mathrm{Brix}\right)\end{array}$ & \multicolumn{2}{|c|}{ Soluble Solids Color } & & \multicolumn{2}{|l|}{ Shade } & \multicolumn{2}{|c|}{$\begin{array}{l}\text { Turbidity } \\
(\%)\end{array}$} \\
\hline & PSPL & PUC & PSPL & PUC & PSPL & PUC & PSPL & PUC & PSPL & PUC & PSPL & PUC \\
\hline 1 & 111.2 & 81.2 & 76 & 75 & 6.5 & 6.7 & 1.76 & 0.83 & 1.40 & 1.37 & 43.7 & 87.4 \\
\hline 2 & 156.2 & 130.6 & 77 & 77 & 6.1 & 6.3 & 2.84 & 3.48 & 1.15 & 1.11 & 16.2 & 20.2 \\
\hline 3 & 108.1 & 103.7 & 79 & 75 & 6.4 & 6.3 & 1.18 & 1.97 & 1.26 & 1.08 & 55.0 & 94.4 \\
\hline 4 & 213.7 & 133.7 & 73 & 75 & 6.0 & 6.1 & 3.95 & 2.19 & 0.94 & 1.12 & 6.9 & 64.7 \\
\hline 5 & 158.7 & 41.9 & 72 & 72 & 6.1 & 5.8 & 4.29 & 1.39 & 0.89 & 1.39 & 5.3 & 51.4 \\
\hline 6 & 192.5 & 78.1 & 70 & 70 & 6.2 & 5.9 & 4.38 & 4.73 & 0.92 & 0.93 & 3.7 & 12.1 \\
\hline
\end{tabular}
Pectinex Ultra SP-L (PSPL) and Pectinex Ultra Clear (PUC) 


\begin{tabular}{lllllllllllll}
\hline 7 & 155.6 & 126.2 & 79 & 75 & 6.3 & 5.6 & 1.31 & 0.29 & 1.24 & 1.52 & 47.5 & 91.8 \\
8 & 226.8 & 138.1 & 73 & 75 & 6.3 & 5.3 & 3.83 & 4.68 & 1.01 & 0.91 & 7.6 & 6.0 \\
9 & 159.3 & 117.2 & 70 & 75 & 5.9 & 6.2 & 1.52 & 0.88 & 1.04 & 1.32 & 39.4 & 67.1 \\
10 & 161.2 & 106.2 & 75 & 80 & 6.1 & 6.4 & 1.60 & 0.99 & 1.03 & 1.37 & 42.6 & 68.0 \\
11 & 163.1 & 114.4 & 75 & 75 & 6.0 & 6.5 & 1.53 & 1.67 & 1.01 & 1.38 & 42.3 & 47.0 \\
\hline
\end{tabular}

Before enzymatic treatment, soft jackfruit showed a high viscosity value, $3553 \mathrm{cP}$, due to its high content of pectinolytic substances. Due to the high hydrolytic activity of these enzymes, a high reduction in pulp viscosity was observed, as well as the attainment of a satisfactorily clarified solution. Both enzyme solutions used in the treatment are pectinases, a group that degrades pectic substances present in the cell wall of plants and belong to the class of hydrolases. Polygalacturonases (PG), the main constituent of enzyme solutions, are depolymerizing enzymes that hydrolyse $\alpha-1,4$ glycosidic bonds between two galacturonic acid residues.

In the enzymatic treatment the conditions of higher time $(100 \mathrm{~min})$, lowest temperature $\left(30^{\circ} \mathrm{C}\right)$ and higher enzyme concentration $(0.09 \%)$ provided the highest viscosity reduction $(96.96 \%)$ using PSPL. Meanwhile, the highest viscosity reduction (98.82\%) using PUC was obtained in the lower time $(20 \mathrm{~min})$, lower temperature $\left(30^{\circ} \mathrm{C}\right)$ and high enzyme concentration $(0.09 \%)$ condition (Table 2). Lowest time $(20 \mathrm{~min})$, temperature $\left(30^{\circ} \mathrm{C}\right)$ and enzyme concentration $(0.01 \%)$ provided the lowest viscosity values (226 and $138 \mathrm{cP}$ ) using PSPL and PUC enzymes respectively. Yield varying between 70 and $80 \%$ was obtained in the conditions evaluated independently of used enzyme (Table 2). Besides as it could be verified in Table 2 , pulps containing soluble solids content between 5.9 and 6.5 and between 5.3 and 6.7 was obtained using PSPL and PUC, respectively. In the conditions evaluated lowest (1.18 and 0.29 ) and highest (4.38 and 4.73) values of color intensity of the pulps were verified after its treatment using PSPL and PUC respectively. Similar lowest values of shade (0.89 and 0.91) were obtained in the treated pulp independently of used enzyme, a highest value of shade (1.52) was verified using PSPL than with PUC (1.40). Highest values of turbidity (55.0 and 94.4) were obtained using higher time $(100 \mathrm{~min})$, lowest temperature $\left(30^{\circ} \mathrm{C}\right)$ and higher enzyme concentration $(0.09 \%)$ independently of used enzyme. Lowest turbidity values $(3.7$ and 6.0) were verified in the conditions of lower values of time $(20 \mathrm{~min})$ and enzyme concentration $(0.01 \%)$ using lower $\left(30^{\circ} \mathrm{C}\right)$ and higher $\left(60^{\circ} \mathrm{C}\right)$ temperature with PSPL and PUC, respectively.

The coefficients for viscosity, color intensity, shade and turbidity of the soft jackfruit pulp treated with Pectinex SP-L and Pectinex Ultra Clear found in the linear models are shown in Tables 3 and 4, respectively with the determination coefficients $\left(\mathrm{R}^{2}\right)$ that describe the proposed models. 
Table 3. Coefficients of linear models describing viscosity, color intensity, shade and turbidity in the enzyme treatment of soft jackfruit pulp with Pectinex Ultra SP-L and coefficient of determination values $\left(\mathrm{R}^{2}\right)$ of each model

\begin{tabular}{lllll}
\hline Coefficient & Viscosity $(\mathrm{cP})$ & Color Intensity $(\mathrm{Abs})$ & Shade $(\mathrm{Abs})$ & Turbidity $(\% \mathrm{~T})$ \\
\hline $\mathrm{b}_{0}$ & 164.2182 & 2.563545 & 1.080273 & 28.2 \\
$\mathrm{~b}_{1}$ & $-18.05^{*}$ & $-0.509^{*}$ & $0.086375^{*}$ & $7.2125^{*}$ \\
$\mathrm{~b}_{2}$ & $-10.7^{*}$ & $0.37525^{*}$ & -0.010875 & $-6.0125^{*}$ \\
$\mathrm{~b}_{3}$ & $-31.95^{*}$ & $-0.8075^{*}$ & $0.095875^{*}$ & $14.6375^{*}$ \\
$\mathrm{~b}_{12}$ & $-2.9^{*}$ & $-0.50575^{*}$ & $0.100625^{*}$ & $5.5125^{*}$ \\
$\mathrm{~b}_{13}$ & $-5.7^{*}$ & $-0.155^{*}$ & $0.045875^{*}$ & $4.2625^{*}$ \\
$\mathrm{~b}_{23}$ & $12.25^{*}$ & $0.51425^{*}$ & $-0.040375^{*}$ & $-7.3625^{*}$ \\
$\mathrm{R}^{2}$ & 0.9916 & 0.7488 & 0.9382 & 0.8085 \\
\hline
\end{tabular}

Note: Subscripts: $1=$ time; $2=$ temperature; $3=$ enzyme concentration

*Significant at 0.05 level.

Table 4. Coefficients of linear models describing viscosity, color intensity, shade and turbidity in the enzyme treatment of soft jackfruit pulp with Pectinex Ultra Clear and coefficient of determination $\left(\mathrm{R}^{2}\right)$ values of each model

\begin{tabular}{lllll}
\hline Coefficient & Viscosity $(\mathrm{cP})$ & Color Intensity $(\mathrm{Abs})$ & Shade $(\mathrm{Abs})$ & Turbidity $(\% \mathrm{~T})$ \\
\hline $\mathrm{b}_{0}$ & 106.4818 & 2.09855 & 1.226982 & 58.1909 \\
$\mathrm{~b}_{1}$ & 8.1125 & -0.327 & -0.008388 & 16.925 \\
$\mathrm{~b}_{2}$ & $-21.2375^{*}$ & 0.162 & 0.020013 & -14.475 \\
$\mathrm{~b}_{3}$ & $-15.9375^{*}$ & $-1.32425^{*}$ & $0.161188^{*}$ & $24^{*}$ \\
$\mathrm{~b}_{12}$ & $14.8375^{*}$ & -0.12525 & $0.049063^{*}$ & -5.9 \\
$\mathrm{~b}_{13}$ & -3.9125 & 0.609 & $-0.106463^{*}$ & -7.275 \\
$\mathrm{~b}_{23}$ & -5.4625 & -0.171 & 0.019088 & 2.625 \\
$\mathrm{R}^{2}$ & 0.9738 & 0.7743 & 0.7665 & 0.8285 \\
\hline
\end{tabular}

Note: Subscripts: $1=$ time; $2=$ temperature; $3=$ enzyme concentration

*Significant at 0.05 level

Statistical analysis showed that in the enzyme treatment of soft jackfruit pulp, regardless of the 
enzyme used, the lack of adjustment was not significant and the satisfactory coefficient of determination values $\left(\mathrm{R}^{2}\right)$ were obtained. The $\mathrm{R}^{2}$ values for viscosity, color intensity, shade and turbidity were $0.9916,0.7488,0.9382$ and 0.8085 , respectively, for treatment with Pectinex Ultra SP-L and 0.9738, 0.7743, 0.7665 and 0.8285, respectively, for treatment with Pectinex Ultra Clear. The coefficients of determination for these variables were greater than 0.74 , indicating that the proposed models adequately explain $(>74 \%)$ the studied responses.

The yield and soluble solids result in the juice treated were not significantly influenced by the factors and their interactions under the studied conditions. Distinct results were verified for treatments with Pectinex Ultra SP-L by Umsza-Guez et al. (2011). These authors observed that, in the treatment of caja-mango juice, the yield $(10.7$ to $16.4 \mathrm{~mL})$ was influenced by all variables studied. In the treatment of carrot juice with pectinase and cellulase prepared from Aspergillus foetidus and Trichoderma reesi, respectively, Sharma, Sakar and Sharma (2005) showed that time, temperature and enzyme concentration positively affected the juice yield ranging from $62.18 . \%$ and $73.66 \%$.

According to Umsza-Guez et al. (2011), understanding how independent variables affect the juice yield in enzyme treatment is not an easy task, since each fruit has different chemical bonds between its constituents. Therefore, the enzyme groups will act differently on each compound, producing different results for the same process conditions

\subsubsection{Viscosity}

The jackfruit pulp has a high viscosity $(3353 \mathrm{cP})$ when compared to other fruits, e.g. soursop pulp, which has a viscosity of $620 \mathrm{cP}$ at $20^{\circ} \mathrm{C}$ (Miranda et al., 2012). It is well known that fruit pulps present non-newtonian rheological behavior (Urlaub, 1996). The viscosity of soft fruit juices, as jackfruit, are caused mainly by the polysaccharides such as pectin. Pectic substances present water holding capacity and that enzyme action would break down the pectin chains releasing captive water and reducing viscosity (Kashyap et al., 2001; Urlaub, 1996).

In the enzymatic treatment larger viscosity reductions (lower than $226.8 \mathrm{cP}$ ) were achieved by using higher enzyme concentrations for both enzymes (Fig 1). Jackfruit pulp treated with Pectinex Ultra SP-L had its initial viscosity reduced by approximately $97 \%$ with values ranging from 108 to $226 \mathrm{cP}$. The Pectinex Ultra Clear enzyme produced an approximate $99 \%$ reduction in initial viscosity, with values ranging from 138.1 to $41.9 \mathrm{cP}$. These results corroborate with the optimal working temperatures for each enzyme. In other words, PUC has greater activity in the conditions of higher temperature $\left(60^{\circ} \mathrm{C}\right)$, thus requiring less hydrolysis time. PSPL has a greater activity at a lowest temperature $\left(30^{\circ} \mathrm{C}\right)$ but requires higher hydrolysis time. Thus, less reduction in viscosity is obtained with lower time, temperature and enzyme concentration regardless of the enzyme used (Table 2).

After enzyme treatment, pectin degradation leads to a reduction in water retention capacity, causing water to be released into the system, reducing juice viscosity (Lee et al., 2006). Enzyme treatment with pectinase was used to reduce viscosity of fruits such as pitanga - from $2.85 \mathrm{mPa}$.s to $1.78 \mathrm{mPa} . \mathrm{s}$ (Ongaratto \& Viotto, 2015), guava - from $17.72 \mathrm{mPa} . \mathrm{s}$ to $0.969 \mathrm{mPa} . \mathrm{s}$ (Ninga et al., 2018) and bananas - up to $1.89 \mathrm{cps}$ (Lee et al., 2006). According to Ninga et al. (2018), this rheological property is reduced by enzyme depectinization, which degrades pectin 


\section{Ml Macrothink}

and other pulp polysaccharides.

Minor viscosity reductions $(85 \%, 80 \%$ and $62.9 \%)$ were reported following hydrolysis of caja-mango pulp with Pectinex Ultra SP-L (Umsza-Guez et al., 2011), mango pulp with Pectinex + Cellucast (Sreenath et al., 1995), and guava juice with Clarex-L (Brasil et al., 1995), respectively.
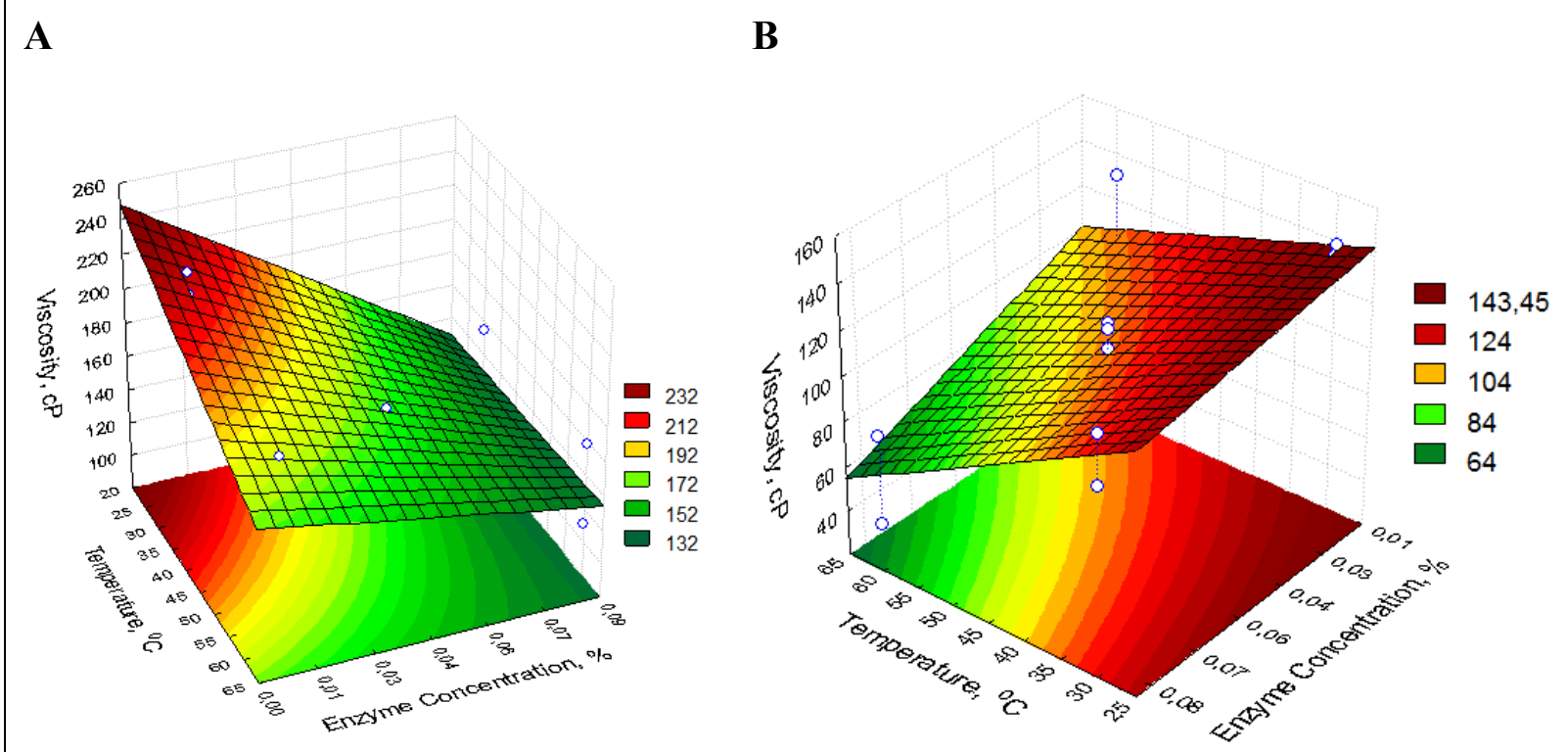

Figure 1. Response surfaces described by the proposed models representing the viscosity of soft jackfruit pulps as a function of temperature and enzyme concentration treated with Pectinex Ultra SP-L (A) and Pectinex Ultra Clear (B)

Viscosity was negatively influenced by the linear effects of time, temperature and enzyme concentration and the interactions of time with temperature and enzyme concentration in the Pectinex Ultra SP-L treatment. The effect of the interaction between temperature and enzyme concentration was the only one that had a positive influence on viscosity (Table 3 ). In the Pectinex Ultra Clear treatment, only the effects of temperature and enzyme concentration were significant at the $95 \%$ confidence level $(\mathrm{p}<0.05)$, with negative influence on viscosity (Table 4). The effect of the interaction between time and temperature was significant at the $95 \%$ confidence level $(\mathrm{p}<0.05)$.

The temperature increases the rate of enzymatic reactions as long as the temperature is below denaturation temperature for the enzyme (Lee at al., 2006). At much high temperatures, the enzyme is denatured and the rate of hydrolysis decreases. The degree of hydrolysis and the effect in the response are influenced also by the enzyme composition and activity. In this specific case, Pectinex Ultra SP-L is a polygalacturonase, composed by $5 \%$ polygalacturonase, and activity of 3800 PGNU, while Pectinex Ultra Clear is a polygalacturonase, composed by $6 \%$ polygalacturonase and $4 \%$ pectin lyase, and activity of 7900 PGNU. Although both are polygalacturonases they have different composition, activities and, mainly, mechanisms of action, which can explain the different behavior and 
result for each enzyme. According to Baumann (1981), the mechanism of pectin hydrolysis can be divided into two stages: the dissolution of protopectin and the degradation of dissolved pectin. The mechanism of pectin degradation largely depends upon the type of enzymes used and the pectic composition of the substrate. Enzymes can be selected to attack preferentially specific pectic substances present. Pectinex Ultra SP-L is an endo-polygalacturonase (PG), from A. niger, also known as poly (1,4- $\alpha$-D-galacturonide) glycanohydrolase, catalyzes random hydrolysis of $\alpha(1,4)$-glycosidic linkages in pectic acid (Tapre \& Jain, 2014). Pectinex Ultra Clear is a combination of two enzymes, an endo-polygalacturonase (endo-PG) and a polymethylegalacturonate lyase (endo-PMGL), which catalyzes random cleavage of $\alpha-1,4$ glycosidic linkages in pectin (Kashyap et al., 2001).

\subsubsection{Color Intensity}

The color intensity of a solution is proportional to the concentration of light-absorbing molecules. The more concentrated the solution, the greater the light absorption (Compri-Nardy et al., 2009). The enzyme Pectinex Ultra SP-L produced lower pulp color intensity (1.18), as well as greater viscosity reduction under the same hydrolysis conditions, using longer time, lower temperature and higher enzyme concentration (Figure 2). All independent variables and their interactions had a significant effect on color intensity at the $95 \%$ confidence level. Time and enzyme concentration had negative linear effect, and temperature positively influenced color intensity.

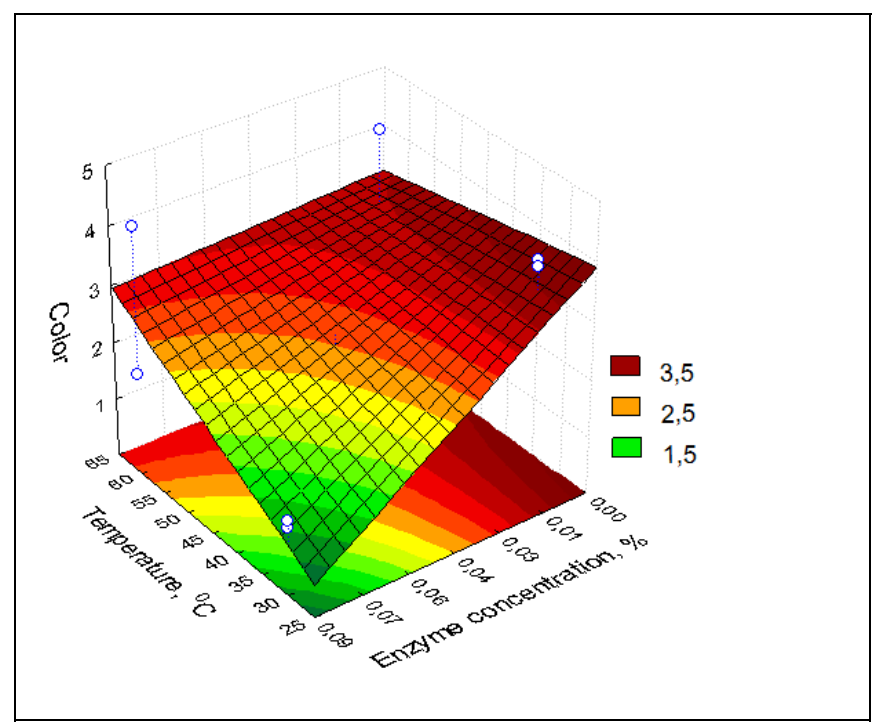

Figure 2. Response surface described by the proposed model for the color intensity of Pectinex Ultra SP-L-treated pulp as a function of enzyme concentration and temperature

For the Pectinex Ultra Clear enzyme, reductions in color standards were significantly influenced by enzyme concentration at the $95 \%$ confidence level, with negative linear effect (Table 4). Interactions had no significant effect on this response.

Similar behaviour was observed by Liew Abdullah et al. (2007) in the treatment of star fruit juice, where the enzyme concentration was the factor that most influenced the clarification and 
the temperature was the minor parameter, since in the model the interactions showed no significant effects on the response. According to Kilara (1982), in general, the time required to obtain a clear juice is inversely proportional to the concentration of enzyme used at constant temperature.

Pectinases degrade pectin, resulting in reduced viscosity and agglomeration, which facilitate separation by centrifugation or filtration. As a result, the juice is clearer and tastier (Liew Abdullah et al., 2007; Kaur et al., 2004).

\subsubsection{Shade}

Tone, shade, or brightness are believed to be terms used to describe how bright or dark a color looks, and it refers to the amount of light perceived. In treatment with Pectinex Ultra SP-L (Table 3), the shade depends mainly on time and enzyme concentration, with positive and significant linear effects $(p<0.05)$. Interactions between time, temperature and enzyme concentration are significant at the $95 \%$ confidence level.

Figure 3 shows the shade's response surface of the clarified pulp as a function of enzyme concentration and time, and it is evident that shade values increase with raising enzyme concentration. The increase in shade values indicates that a greater clarification of the pulp was obtained.

In the treatment with Pectinex Ultra Clear, only the enzyme concentration has a significant effect (Table 4), with $p<0.05$, demonstrating that shade depends mainly on this variable. The interactions of time with temperature and enzyme concentration were significant at $p<0.05$, with positive and negative linear effects, respectively. High concentrations of pectinase positively affect shade; i.e., they cause an increase in this parameter producing a greater clarification of the pulp (Fig 3).

Both pectinases used in the treatments have the same composition, differing only in the values of polygalacturonase activity, a fact that could justify the similarities in the results obtained. The action of polygalacturonase leads to extensive degradation of the middle lamella and pectin of the cell walls, so the resulting pulp has low viscosity and the amount of waste is reduced, causing a crystalline appearance in the final product (Uenojo \& Pastore 2007). 


\section{Ml Macrothink}

A

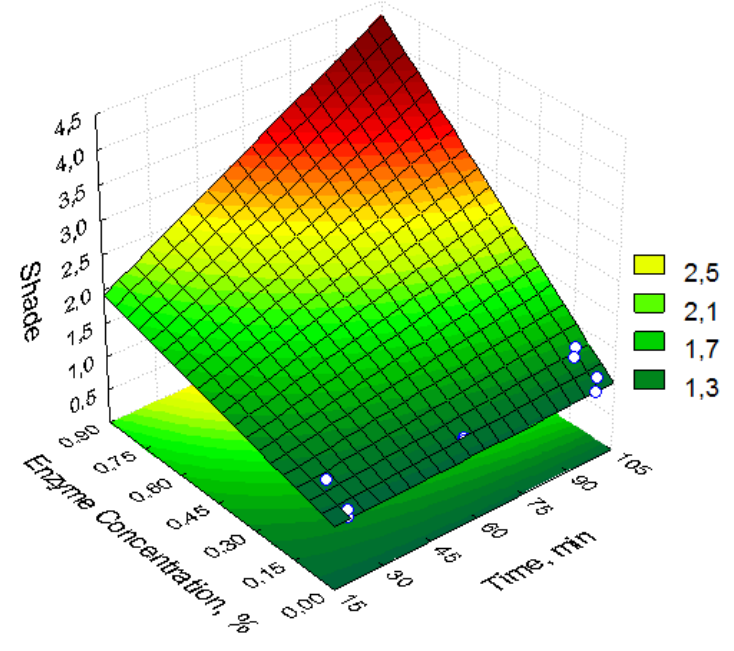

Journal of Applied Biotechnology

ISSN 2327-0640

2021, Vol. 9, No. 1

Figure 3. Response surfaces described by the proposed model for the soft jackfruit pulp shade as a function of enzyme concentration and time treated with Pectinex Ultra SP-L (A) and Pectinex Ultra Clear (B)

\subsubsection{Turbidity}

The turbidity of fruit juices is mainly caused by the presence of polysaccharides such as pectin (Grassin \& Fauquembergue, 1999). Turbidimetry is an analytical technique based on the measurement of turbidity by scattering light in a medium caused by particles (suspension or colloids) (McPherson \& Pincus, 2006). The greater the number of particles (turbidity) in the sample, the greater the spread of radiation and, therefore, the less radiation will reach the detector, with less transmittance. In this case, clarified samples have high transmittance values (\%) and, consequently, low turbidity.

The turbidity of the soft jackfruit pulp was significantly influenced by the effect of all independent variables and their interactions at the $95 \%$ confidence level in the treatment with Pectinex Ultra SP-L, having a determination coefficient $\left(\mathrm{R}^{2}\right)$ value of 0.8085 . An increase in the enzyme concentration at low temperatures $\left(30^{\circ} \mathrm{C}\right)$ produced a reduction in turbidity of the jackfruit pulp (Fig 4). In fact, long exposition to high enzyme concentrations are likely to break down pectic substances exposing positive nucleus sites to surrounding negative charges, settling out the so formed large protein-pectin particles (Kashyap et al., 2001). Increase in enzyme concentration and incubation time might decrease turbidity. Pectin was the main cause of turbidity, as the clarification process took place, the amount of pectin in the juices decreased, therefore reducing the turbidity (Alvarez et al., 1998; Lee et al., 2006).

Similar behaviour was verified by Liew Abdullah et al. (2007), in the treatment of star fruit juice with Pectinex Ultra SP-L, where the author shows that at a given temperature $\left(30^{\circ} \mathrm{C}\right)$, the turbidity was reduced to $16.97 \mathrm{NTU}$ with an increase in the enzyme concentration from $0.01 \%$ to $0.055 \%$. 


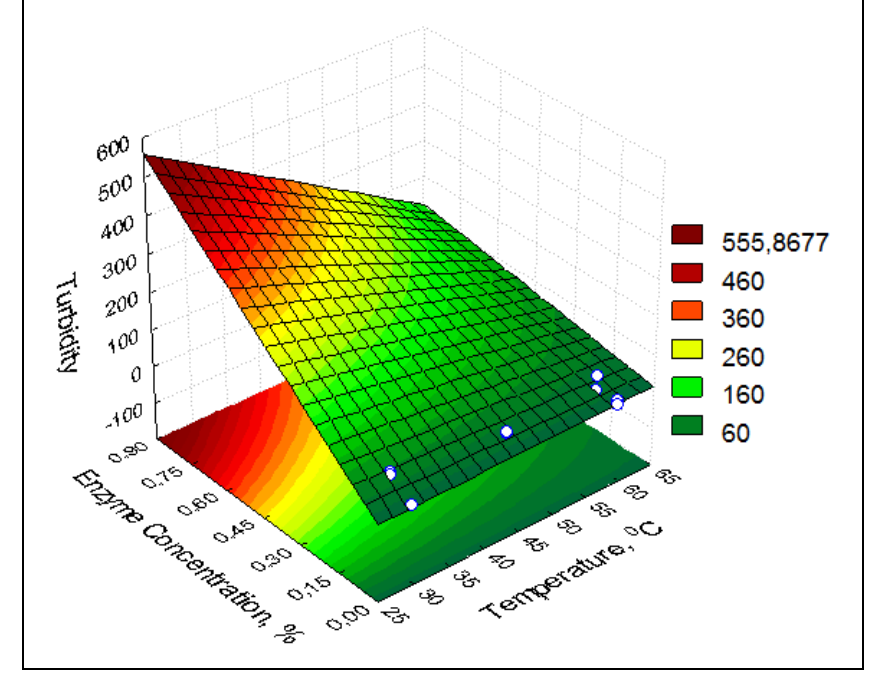

Figure 4. Response surface described by the proposed model for the turbidity of soft jackfruit pulp treated with Pectinex Ultra SP-L as a function of enzyme concentration and temperature

In the pulp treated with Pectinex Ultra Clear, turbidity was subject to enzyme concentration with a positive linear effect (Table 4). The other variables as well as the interactions between them were not significant for this response. The jackfruit pulp showed high clarification with increased enzyme concentration, regardless of the time and temperature of the treatment. Similar behaviour was reported by Lee et al. (2006) in the hydrolysis of banana juice with pectinase and amylolytic enzymes, where turbidity was reduced from 28.4 to 2.3 NTU. The action of pectinases is mainly related to the reduction of turbidity caused by the presence of pectin in fruit juices (Pinelo et al., 2010; Sandri et al., 2011; Maktouf et al., 2014).

It is possible to say that, for both enzymes, greater reductions in viscosity and turbidity were obtained under similar hydrolysis conditions; i.e., using the highest enzyme concentration. Such results demonstrate the strong correlation between reduced viscosity and clarification of the pulp after enzyme treatment.

According to Uenojo \& Pastore (2007), pectic substances are responsible for the consistency, turbidity and appearance of fruit juices, causing a considerable increase in viscosity. The addition of pectinolytic enzymes results in pectin degradation, decreasing viscosity, and causing a crystalline appearance in the final product.

\section{Conclusion}

Time, temperature and higher values of enzyme concentration (Pectinex Ultra SP-L) significantly affected viscosity, color intensity and turbidity of jackfruit pulps. With the use of Pectinex Ultra-Clear, viscosity, color intensity, shade and turbidity of the jackfruit pulp were expressively affected using higher enzyme concentration, regardless of the time and temperature used. In both treatments, the yield and soluble solids content were not affected by the independent variables.

It was found that in the treatment with pectinolytic enzymes there is a direct relation between the reduction of viscosity and the reduction of turbidity. Due to the high hydrolytic activity, there is degradation of pectin, release of water and consequent attainment of less viscous and turbid solutions. 


\section{Acknowledgments}

This work was supported by Coordenação de Aperfeiçoamento de Pessoal de Nível Superior (CAPES) - Brazil, Financial Code 001. We thank the Graduate Program of Biotecnology (PPGBiotec) of the State University of Feira de Santana (UEFS) for all support and LNF Latin America and Novozymes by donating the enzymes.

\section{References}

Almeida, C., Brányik, T., Moradas-Ferreira, P., \& Teixeira, J. (2005). Use of two different carriers in a packed bed reactor for endopolygalacturonase production by a yeast strain. Process Biochemistry, 40, 1937. https://doi.org/10.1016/j.procbio.2004.07.008

Andrade, P. F. S. (2017). Fruticultura: Análise da conjuntura agropecuária safra 2016/17. Paraná: Secretaria da agricultura e do abastecimento departamento de economia rural. https://doi.org/10.1590/0100-29452017690

Asquieri, E. R., Rabelo, A. M. S., \& Silva, A. G., 2008. Fermentado de jaca: estudo das características físico-químicas e sensoriais. Ciência e Tecnologia de Alimentos, 28(4), 881-887. https://doi.org/10.1590/S0101-20612008000400018

Bhattacharya, S., \& Rastogi, N. K. (1998). Rheological Properties of Enzyme-treated Mango Pulp. Journal of Food Engineering, 36, 249-262. https://doi.org/10.1016/S0260-8774 (98)00067-3

Begum, R., Aziz, M. G., Uddin, M. B., \& Yusof, Y. A. (2014). Characterization of Jackfruit (Artocarpus Heterophyllus) Waste Pectin as Influenced by Various Extraction Conditions. Agriculture and Agricultural Science Procedia, 2, 44-251. https://doi.org/10.1016/j. aaspro.2014.11.035

Brasil, I. M., Maia, G. A., \& Figueiredo, R. W. (1995). Physical-chemical changes during extraction and clarification of guava juice. Food Chemistry, 54, 383-386. https://doi.org/10. 1016/0308-8146(95)00066-R

Brazilian Fruit Yearbook. (2017). Santa Cruz do Sul: Editora Gazeta, pp 88. Available at: http://www.editoragazeta.com.br/sitewp/wp-content/uploads/2017/03/PDF-Fruticultura_2017 .pdf. Acessed 03 march 19.

Buainain, A. M., \& Batalha, M. O. (2007). Cadeia Produtiva de Frutas. Brasília: IICA/MAPA/SPA, 7, p. 102. http://repiica.iica.int/docs/B0588p/B0588p.pdf. Acessed 09 apr 19

Cheirsilp, B., \& Umsakul, K. (2008). Processing of banana based wine product using pectinase and $a$-Amylase. Journal of Food Process Engineering, 31(1), 78-90. https://doi.org/10.1111/j. 1745-4530.2007.00152.x

Compri-Nardy, M., Stella, M. B., \& Oliveira, C. (2009). Práticas de Laboratório de Bioquímica e Biofísica. Guanabara Koogan, Rio Grande do Sul.

Fachinello, J. C., Pasa, M. S., Schmtiz, J. D., \& Betemps, D. L. (2011). Situação e perspectivas da fruticultura de clima temperado no brasil. Revista Brasileira de Fruticultura, 109-120. https://doi.org/10.1590/S0100-29452011000500014

Glories, Y. (1984). La couleur des vins rouges. 2ème partie mesure, origine et interpretation. 
Connaissance de la Vigne et $d u$ Vin, 18, 253-271. https://doi.org/10.20870/oeno-one. 1984.18.4.1744

Goswami, C., \& Chacrabati, R. (2016). Jackfruit (Artocarpus heterophylus). Nutr. Comp. Fruit Cult. 317-335. https://doi.org/10.1016/B978-0-12-408117-8.00014-3

Grassin, C., \& Fauquembergue, P. (1999). Enzymes, fruit juice processing. In M. C. Flickinger, \& S. W. Drew (Eds.), Encyclopedia of bioprocess technology, fermentation, biocatalysis, bioseparation. John Wiley and Sons, New York.

Jagtap, U. B., Waghmare, S. R., Lokhande, V. H., Suprasanna, P., \& Bagtap, V. A. (2011). Preparation and evaluation of antioxidant capacity of Jackfruit (Artocarpus heterophyllus Lam.) wine and its protective role against radiation induced DNA damage. Industrial Crops and Products, 34(3), 1595-1601. https://doi.org/10.1016/j.indcrop.2011.05.025

Jagtap, U. B., \& Bapat, V. A. (2010). Artocarpus: a review of its traditional uses, phyto-chemistry and pharmacology. Journal of Ethnopharmacol, 129, 142-166. https://doi.org/10.1016/j.jep.2010.03.031

Kaur, G., Kumar, S., \& Satyanarayana, T. (2004). Production, characterization and application of a thermostable polygalacturonase of a thermophilic moul Sporotrichum Termophile. Bioresource Technology, 94, 239-243. https://doi.org/10.1016/j.biortech.2003. 05.003

Kumar, S. (2015). Role of enzymes in fruit juice processing and its quality enhancement. Advances in Applied Science Research, 6(6), 114-124.

Lee, W. C., Yusof, S., Hamid, N. S. A., \& Baharin, B. S. (2006). Optimizing conditions for enzyme clarification of banana juice using response surface methodology (RSM). Journal of Food Engineering, 73, 55-63. https://doi.org/10.1016/j.jfoodeng.2005.01.005

Liew Abdullah, A. G. L., Sulaiman, N. M., Aroua, M. K., \& Megat Mohd Noor, M. J. (2007). Response surface optimization of conditions for clarification of carambola fruit juice using a commercial enzyme. Journal of Food Engineering., 81(1), 65-71. https://doi.org/10.1016/j. jfoodeng.2006.10.013

Maktouf, S., Neifar, M., Drira, S. J., Baklouti, S., Fendri, M., \& Châabouni, S. E. (2014). Lemon juice clarification using fungal pectinolytic enzymes coupled to membrane ultrafiltration. Food and Bioproducts Processing, 92(1), 14-19. https://doi.org/10.1016/j. fbp.2013.07.003

McPherson, R. A., \& Pincus, M. R. (2006). Henry's clinical diagnosis and management by laboratory methods. WB Saunders, Philadelphia, 37-63.

Mieszczakowska-Frac, M., Markowski, J., Zbrzezniak, M., \& Plocharski, W. (2012). Impact of enzyme on quality of blackcurrant and plum juices. LWT - Food Science and Technology, 49, 251-256. https://doi.org/10.1016/j.lwt.2011.12.034

Miranda, V. A. M., Queiroz, A. J. M., Figueirêdo, R. M. F., \& Santos, D. C. (2012). Viscosidade aparente de polpas de graviola com diferentes concentrações. Revista Brasileira de Produtos Agroindustriais, 14, 423-434. https://doi.org/10.15871/1517-8595/rbpa.v14n Especialp423-434

Ninga, K. A., Sengupta, S., Jain, A., Desobgo, S. C., Jong Nso, E., \& De, S. (2018). Kinetics of 
enzyme hydrolysis of pectinaceous matter in guava juice. Journal of Food Engineering, 221,158-166. https://doi.org/10.1016/j.jfoodeng.2017.10.022

Ongaratto, R. S., \& Viotto, L. A. (2015). Efeito do tratamento enzimático sobre a viscosidade e os teores de fibra e pectin em suco de pitanga (Eugenia uniflora L.). Brazilian Journal of Food Technology, 18(3), 231-238. https://doi.org/10.1590/1981-6723.5514

Patel, A.K., Singhania, R.R., \& Pandey, A. (2016). Novel enzymatic processes applied to the food industry. Current Opinion Food Science, 7, 64-72. https://doi.org/10.1016/j.cofs. 2015.12.002

Pinelo, M., Zeuner, B., \& Meyer, A. S. (2010). Juice clarification by protease and pectinase treatments indicates new roles of pectin and protein in cherry juice turbidity. Food and Bioroducts Processing, 88(2-3), 259-265. https://doi.org/10.1016/j.fbp.2009.03.005

Pollard, A., \& Kieser, M. E. (1951). The pectase activity of apples. Journal of the Science of Food and Agriculture, 2(1), 30-36. https://doi.org/10.1002/jsfa.2740020105

Raveendran, S., Parameswaran, B., Ummalyma, S. B., Abraham, A., Mathew, A. K., Madhavan, A., ... Pandey, A. (2018). Applications of microbial enzymes in food industry. Food Technology and Biotechnology, 56(1), 16-30. https://doi.org/10.17113/ftb.56.01. 18.5491

Reed, B. J., Hendrix Jr., C. M., \& Hendrix, D. L. (1986). Quality Control for Citrus Processing Plants. Intercit, Florida.

Rezic, T., Oros, D., Markovic, I., Kracher, D., Ludwig, R., \& Santek, B. (2013). Integrated Hydrolization and fermentation of sugar beet pulp to bioethanol. Journal of Microbiology and Biotechnology, 23(9), 1244-1252. https://doi.org/10.4014/jmb.1210.10013

Sandri, I. G., Fontana, R. C., Barfknecht, D. M., \& Silveira, M. M. (2011). Clarification of fruit juices by fungal pectinases. LWT - Food Science and Technology, 44(10), 2217-2222. https://doi.org/10.1016/j.lwt.2011.02.008

Sharma, A. K., Sarkar, B. C., \& Sharma, H. K. (2005). Optimization of enzyme process parameters for increased juice yield from carrot (Daucus carota L.) using response surface methodology. European Food Research and Technology, 221, 106-112. https://doi.org/10.1007/s00217-005-1203-7

Silva, J. H. V., Jordão Filho, J., Ribeiro, M. L. G., \& Silva, E. L. (2007). Effect of the addition of jackfruit (Artocarpus heterophyllus Lam.) seeds bran in dietary on the egg production, yolk pigmentation and dropping humidity in Japanese quais. Ciência e Agrotecnologia, 31, 523-530. https://doi.org/10.1590/S1413-70542007000200037

Sin, H. N., Yusof, S., Sheikh Abdul Hamid, N., \& Abd. Rahman, R. (2006). Optimization of enzyme clarification of sapodilla juice using response surface methodology. Journal of Food Engineering, 73, 313-319. https://doi.org/10.1016/j.jfoodeng.2005.01.031

Souza, T. S., Chaves, M. A., Bonomo, R. C. F., Soares, R. D., Pinto, E. G. E., \& Cota, I. R. (2009). Desidratação osmótica de frutículos de jaca (Artocarpus integrifólia L.): aplicação de modelos matemáticos. Acta Scientarium Technology, 31(2), 225-230. https://doi.org/10.4025/ actascitechnol.v31i2.1026 
Sreenath, H. K., Sudarshanakrishna, K. R., \& Santhanam, K. (1995). Enzymatic liquefaction of some varieties of mango pulp. Lebensmittal-Wissenschafi-und-Technology, 28, 196-200. https://doi.org/10.1016/S0023-6438(95)91424-2

Subburamu, K., Singaravelu, M., Nazar, A., \& Irulappan, I. (1992). A study on the utilization of jackfruit waste. Bioresource Technology, 40, 85-86. https://doi.org/10.1016/09608524(92)90125-H

Swami, S. B., Thakor, N. J., Haldankar, P. M., \& Kalse, S. B. (2012). Jackfruit and Its Many Functional Components as Related to Human Health: A Review. Comprehensive Reviews in Food Science and Food Safety, 11, 565-576. https://doi.org/10.1111/j.1541-4337.2012.00210.x

Tapre, A. R., \& Jain, R. K. (2014). Pectinases: Enzymes for fruit processing industry. International Food Research Jounal, 21(2), 447-453.

Tulyathana, V., Tananuwonga, K., Songjinda, P., \& Jaiboonb, N. (2002). Some Physicochemical Properties of Jackfruit (Artocarpus heterophyllus Lam) Seed Flour and Starch. Science Asia, 28, 37-41. https://doi.org/10.2306/scienceasia1513-1874.2002.28.037

Udayasoorian, L. P., Peter, M. J., Renuka, V., Meenatchisundaram, S., Aafrin, V., Sudharshan, K., ... Muthusamya, S. (2019). Symbiotic impact of honey treatment and package atmosphere on quality retention and shelf life extension of jackfruit bulbs. Scientia Horticulturae, 246, 161-167. https://doi.org/10.1016/j.scienta.2018.10.057

Uenojo, M., \& Pastore, G. M. (2007). Pectinolytic enzymes: Industrial applications and future perspectives. Quimica Nova, 30(2), 388-394. https://doi.org/10.1590/S0100-4042200700 0200028

Umsza-Guez, M. A., Idi, R. R., Vanzela, E. S. L., Martin, N., Silva, R., Gomes, E., \& Thoméo, J. C. (2011). Effect of pectinolitic enzymes on the physical properties of caja-manga (Spondias cytherea Sonn.) pulp. Ciência e Tecnologia de Alimentos, 31(2), 517-526. https://doi.org/10. 1590/S0101-20612011000200037

\section{Copyright Disclaimer}

Copyright reserved by the author(s).

This article is an open-access article distributed under the terms and conditions of the Creative Commons Attribution license (http://creativecommons.org/licenses/by/4.0/). 